\title{
A new Muelleria species (Bacillariophyta) from the Maritime Antarctic Region
}

\author{
Natalia Kochman-KęDziora ${ }^{1 *}$, Teresa Noga ${ }^{1}$, Bart VAn DE VIJver ${ }^{2,3} \&$ Jadwiga \\ STANEK-TARKOWSKA ${ }^{1}$
}

\author{
${ }^{1}$ University of Rzeszow, Faculty of Biology and Agriculture, Podkarpackie Innovative Research Center of En- \\ vironment, Zelwerowicza 8B, 35-601 Rzeszow, Poland; *Corresponding author e-mail: kochman_natalia@ \\ wp.pl \\ ${ }^{2}$ Botanic Garden Meise, Department of Bryophytes \& Thallophytes, Nieuwelaan 38, B-1860 Meise, Belgium \\ ${ }^{3}$ University of Antwerp, Department of Biology, ECOBE, Universiteitsplein 1, B-2610 Wilrijk, Belgium
}

\begin{abstract}
During a survey conducted on the soil diatom flora of newly exposed areas due to the retreat of the Ecology Glacier (King George Island, South Shetlands) an unknown Muelleria taxon was observed that could not be identified using the currently available literature. Based on detailed morphological observations using LM and SEM microscopy the unknown taxon has been described as new for science - Muelleria olechiae sp. nov. The new species is characterized in having typically bifurcated terminal raphe fissures, elongated, deflected proximal raphe endings and a lack of canal puncta. It was observed in several soil samples, but always in relatively low abundances.
\end{abstract}

Key words: Antarctic Region, diatoms, Ecology Glacier forefield, King George Island, Muelleria, taxonomy

\section{INTRODUCTION}

The genus Muelleria was recognized by FrenguelLI $(1924,1945)$ as distinct from Navicula sensu lato based on a combination of several morphological features: unilaterally deflected proximal raphe endings and the presence of two longitudinal ribs running on each site of the raphe. Detailed Scanning Electron Microscope (SEM) analysis allowed recently to reveal more morphological features such as the presence of typical canal puncta (VAN DE VIJVER et al. 2010) separating the genus Muelleria from all other naviculoid genera known so far. Based on this combination of features, several former Navicula and Diploneis taxa were transferred to Muelleria and more than 20 new taxa were described (Spaulding \& Stoermer 1997; SpauldING et al. 1999; VAN DE VIJVER et al. 2010, 2014; Bahls 2014; ZiDARova et al. 2016). At the moment, almost 40 different taxa are present in the genus Muelleria (GuIRY in Guiry 2016). Most of these taxa have a distribution restricted to the Antarctic Region.

The genus Muelleria prefers wet to semi-dry terrestrial (soil) habitats where they dominate the diatom flora together with Humidophila, Luticola and Hantzschia (VAN DE VIJVER et al. 2014). During a sur- vey on the soil diatom flora from Admiralty Bay Region (King George Island, South Shetland Islands) an unknown Muelleria taxon was observed that could not be identified using the currently available literature. Based on detailed LM and SEM observations and comparison with other Muelleria taxa from the Antarctic Region, the taxon is described as a species new to science: Muelleria olechiae sp. nov. Data on its ecological preferences and the associated diatom flora in samples are provided.

\section{STUdy AREA}

King George Island $\left(61^{\circ} 54^{\prime}-62^{\circ} 16^{\prime} \mathrm{S}, 57^{\circ} 35^{\prime}-59^{\circ} 02^{\prime} \mathrm{W}\right)$ is the largest island of the South Shetland Archipelago. It belongs to the Maritime Antarctic Region. The South Shetland Islands are the warmest region of Antarctica (KING \& TURNER 1997) with average temperatures oscillating around $0{ }^{\circ} \mathrm{C}$ throughout the year. Strong winds, high air humidity and constant cloud cover are characteristic for this part of the Antarctic Region (RAKusA-SuszczewsKi 2002). The survey of the soil diatom flora at Admiralty Bay focused on the ice-free area exposed by the retreating Ecology Glacier, situated south of the Polish H. Arctowski Station, in the territory of Antarctic Specially Protected Area No. 128. 


\section{Material And Methods}

Material for the study was collected during the Polish Antarctic Expedition from Ecology Glacier forefield in January and February 2015. The unknown Muelleria taxon was found in six samples:

EcotA10.2015 (Ecology Glacier forefield, King George Island, leg. M. Olech, 13 January 2015) soil, GPS: 62 $12^{\circ} 02.0^{\prime \prime}$ S/ $58^{\circ} 27^{\prime} 37.4^{\prime \prime} \mathrm{W}$.

EcotA11.2015 (Ecology Glacier forefield, King George Island, leg. M. Olech, 13 January 2015) soil, GPS: $62^{\circ} 10^{\prime}$ $03.6^{\prime \prime} \mathrm{S} / 58^{\circ} 27^{\prime} 40.9^{\prime \prime} \mathrm{W}$.

EcotA13.2015 (Ecology Glacier forefield, King George Island, leg. M. Olech, 13 January 2015) soil, GPS: $62^{\circ} 10^{\prime}$ $07.1^{\prime \prime} \mathrm{S} / 58^{\circ} 27^{\prime} 50.9^{\prime \prime} \mathrm{W}$.

EcotB5.2015 (Ecology Glacier forefield, King George Island, leg. M. Olech, 06 February 2015) soil, GPS: $62^{\circ} 09^{\prime}$ $57.9^{\prime \prime} \mathrm{S} / 58^{\circ} 28^{\prime} 04.0^{\prime \prime} \mathrm{W}$.

EcotB7.2015 (Ecology Glacier forefield, King George Island, leg. M. Olech, 06 February 2015) soil, GPS: $62^{\circ} 10^{\prime}$ $01.5^{\prime \prime} \mathrm{S} / 58^{\circ} 28^{\prime} 04.0^{\prime \prime} \mathrm{W}$.

EcotC4.2015 (Ecology Glacier forefield, King George Island, leg. M. Olech, 10 February 2015) soil, GPS: $62^{\circ} 10^{\prime}$ $05.6^{\prime \prime} \mathrm{S} / 58^{\circ} 28^{\prime} 12.7^{\prime \prime} \mathrm{W}$.

At each sampling site, a small soil sample (approx. $100 \mathrm{~g}$ ) was collected using a spoon. The physico-chemical data of soil samples include: $\mathrm{pH}_{\mathrm{H} 2 \mathrm{O}}$, organic carbon content (TJURIN 1965) and nitrogen content determined via the Kjeldahl method using 2300 Kjeltec Analyzer Unit, Foss Tecator Hőganas, Sweden (OstrowsKA et al. 1991) .

For diatom analysis, samples were prepared according to the method used by KAWECKA et al. (1998) and KAWECKA (2012). In order to obtain cleaned diatom valves, small subsamples were digested in a chromic acid cleaning mixture (mixture of concentrated sulfuric acid and chromic acid in proportion 3:1) and then washed using a centrifuge (2500 rpm). Excess inorganic soil matter was removed by sedimentation. Cleaned diatom valves were mounted in Pleurax (refractive index 1.75) and identified using a Carl Zeiss Axio Imager.A2 light microscope (LM) equipped with Differential Interference Contrast (Nomarski) optics. Diatom images were captured with the Zeiss AxioCam HR camera. Samples and slides are stored at the Podkarpackie Innovative Research Center of Environment (PIRCE), University of Rzeszow, Poland. For scanning electron microscopy (SEM), part of the oxidized suspension was filtered through a 3- $\mu \mathrm{m}$ Isopore $^{\mathrm{TM}}$ polycarbonate membrane filter (Merck Millipore), air-dried and attached to aluminum stubs. The stub was sputter-coated with a $20 \mathrm{~nm}$ Gold layer using the Turbo-Pumped Sputter Coater Quorum Q 150OT ES and studied in a Hitachi SU 8010 microscope at $5 \mathrm{kV}$ at PIRCE.

Diatom terminology follows BARBER \& HAWORTH (1981), Round et al. (1990) and VAN DE ViJVER et al. (2010). For the new taxon, the number of specimens measured in the type population is indicated $(\mathrm{n}=30)$.

The new species was compared with similar taxa from the Antarctic Region (Spaulding \& Stoermer 1997;
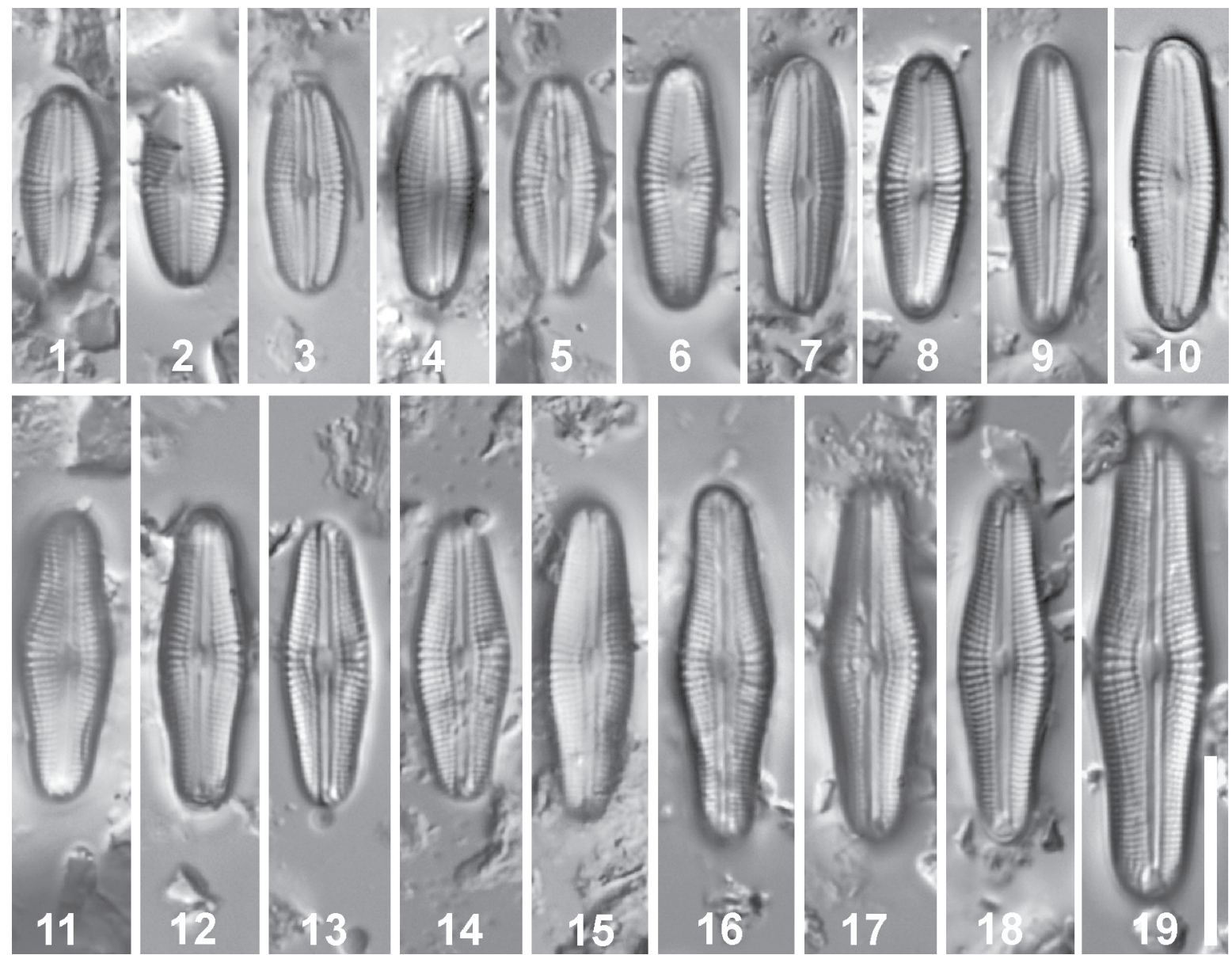

Figs 1-19. Muelleria olechiae sp. nov. LM images of holotype population from King George Island, South Shetland Islands. Scale bar $10 \mu \mathrm{m}$. 
SPAulding et al. 1999; VAN DE ViJVER et al. 2010, 2014; BAHLS 2014; ZiDAROVA et al. 2016)

\section{Results}

\author{
Division Bacillariophyta \\ Class Bacillariophyceae \\ Subclass Bacillariophycidae \\ Order Naviculales \\ Family Naviculaceae \\ Genus Muelleria
}

\section{Muelleria olechiae sp. nov. (Figs 1-27)}

Light microscopy (Figs 1-19): Smaller valves strictly elliptic (Figs 1-7), larger specimens linear-lanceolate with a clearly gibbous central part (Figs 8-19). Apices broadly rounded, not protracted. Valve dimensions $(\mathrm{n}=30)$ : length 13.0-28.5 $\mu \mathrm{m}$ (average $=17.8 \pm$ 4.6), width 5.0-7.0 $\mu \mathrm{m}$ (average $=5.8 \pm 0.6$ ). Axial area fairly narrow, almost entirely linear. Central area formed by slight widening of the axial area, usually rather small. Raphe filiform and straight. Proximal raphe endings unilaterally deflected, usually not extending into the first row of areolae. Terminal raphe fissures deflected to the same side as the proximal endings. Longitudinal canals (visible as longitudinal lines) positioned on either side of the axial area. Striae in the central area (4-6 striae) more widely spaced and more strongly radiate compared to the other striae, central striae 18-21 in $10 \mu \mathrm{m}$, distal striae 23-25 (29) in 10 $\mu \mathrm{m}$ (average $=21 \pm 2$ ). Areolae clearly visible.

Scanning electron microscopy (Figs 20-27): Striae uniseriate composed of small, rounded or slightly transapically elongated areolae $(24-25$ in $10 \mu \mathrm{m}$ in larger valves, up to 33 in $10 \mu \mathrm{m}$ in smaller valves), continuing without interruption onto the valve mantle (Figs 20, 24, 25, 27). Mantle edge lacking any areolae (Fig. 27). Near the axial area one row of apically elongated areolae, becoming transapically elongated, usually in large valves (Figs 22-24). Canal puncta next to the distal raphe endings absent or not separable from the normal areolae. Proximal raphe ends unilaterally deflected, usually not extending into the first row of areolae although occasionally observed in smaller valves (Figs 20, 25). Distal raphe endings deflected to the same side as proximal endings, clearly bifurcated at valve termination (Figs 20-24, 26). Cingulum in the connection of bands with a single row of porelli (Figs 20, 27). Internally, areolae covered by vela. Longitudinal canals quite indistinctly terminating at the helictoglossae (Figs 28, 29).

Holotype: EcotC4.2015 (Podkarpackie Innovative Research Center of Environment (PIRCE), University of Rzeszow, Poland). The valve representing the holotype is here illustrated in Figure 9.
Isotype: BR-4466 (Botanic Garden Meise, Belgium), PLP-316 (University of Antwerp, Belgium)

Type locality: Ecology Glacier forefield, King George Island, South Shetlands, sample EcotC4.2015 (leg. M. Olech, coll. date 13 January 2015)

Etymology: The species is named after our dear friend - Prof. dr. Maria Olech (Jagiellonian University, Krakow, Poland), member of many Polish Antarctic Expeditions, who collected all samples analyzed in this study.

Ecology and distribution: So far the species was only found in very small numbers in several soil samples taken on the Ecology Glacier forefield. The largest population (relative abundance $<2.5 \%$ ) was found in soil sample EcotC4.2015 having an almost circumneutral $\mathrm{pH}(6.7)$ and very low values of organic carbon $(0.18 \%)$ and nitrogen $(0.02 \%)$. The sample is dominated by Hantzschia amphioxys fo. muelleri Ko-BAYASHI, several Humidophila and Luticola species such as Luticola quadriscrobiculata VAN DE VIJVER, L. muticopsis (VAN Heurck) D. G. MANN and Luticola cf. pusilla VAN de Vijver, Kopalová, Zidarova et Levkov. In general, the new taxon was found at a $\mathrm{pH}$ range of 6.7-8.2 and low organic carbon values $(0.10-0.4 \%)$.

\section{Discussion}

Several Antarctic Muelleria taxa show some morphological similarity to the new Muelleria olechiae. The most similar species is Muelleria subsabbei VAN DE ViJver, Zidarova et Kopalová . Both species have a similar elliptic to linear-lanceolate valve outline, but larger forms of Muelleria olechiae have a clearly gibbous central part of the valve contrary to M. subsabbei that never shows this gibbous part. Moreover, M. subsabbei has a completely different raphe structure lacking the typical bifurcated terminal raphe fissures. The latter has simple, hooked terminal fissures, entirely positioned on the valve face. The canal puncta in $M$. subsabbei are more developed contrary to M. olechiae where canal puncta could not with certainty be separated. The more distantly spaced radiate striae in the central area are a feature that is often observed in Muelleria taxa. Muelleria meridionalis Spaulding et StoERMER, M. australoatlantica VAN DE VIJVER et SPAUldING, M. cryoconicola Stanish et Spaulding, M. tumida VAn de ViJver et Spaulding, M. desseiniana VAN DE ViJver, Zidarova et Kopalová and $M$. pimpireviana Zidarova, Kopalová et Van de ViJver all possess these more distantly spaced central striae (SPAULDING et al. 1999; VAN DE VIJVER et al. 2010, 2014; ZidAROVA et al. 2016). All of them however can be separated from the new species. Muelleria meridionalis and M. cryonicola, both known only from the Antarctic Continent, and $M$. australoatlantica never show bifurcated terminal raphe fissures and several clearly developed canal 

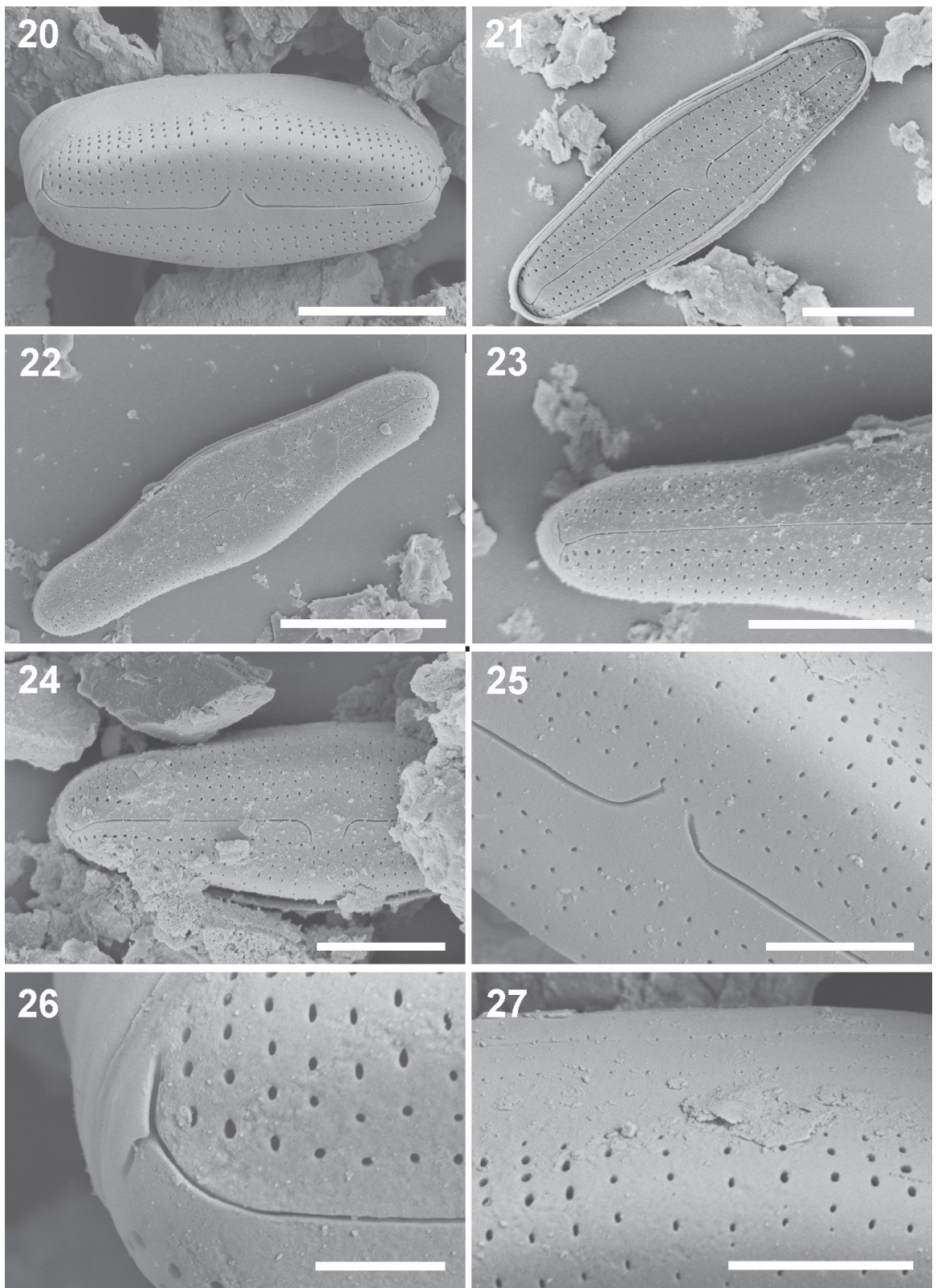

Figs 20-27. Muelleria olechiae sp. nov. SEM images of external valve view taken from holotype population: (20-22) an entire valve view showing variation in the shape; (23-24) view of valve apex and central area; (25) detailed view of the central area, proximal endings and areolae; (26) detailed image of distal raphe endings, clearly bifurcated at valve termination; (27) detailed view on perforated cingulum. Scale bar $10 \mu \mathrm{m}(22), 5 \mu \mathrm{m}(20-21,23-24), 2 \mu \mathrm{m}(25,27), 1 \mu \mathrm{m}(26)$.

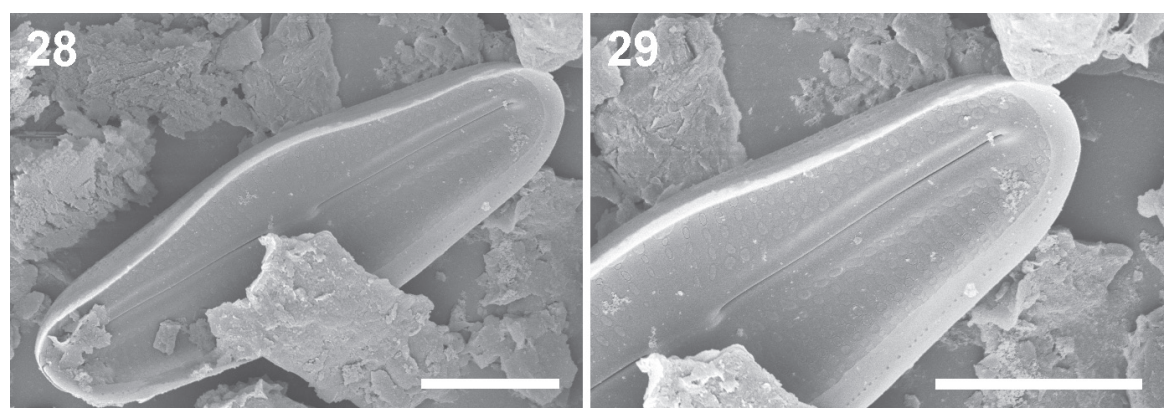

Figs 28-29. Muelleria olechiae sp. nov. SEM images of internal valve view taken from holotype population. Scale bar $5 \mu \mathrm{m}$. 
puncta (see SPAULDING et al. 1999, fig. 95 and VAN DE ViJVER et al. 2010, fig. 25). Muelleria tumida has a different valve outline with protracted, rostrate apices and clearly enlarged areolae bordering the axial area, a feature absent in M. olechiae (VAN DE VIJVER et al. 2010). Smaller specimens of $M$. olechiae and $M$. pimpireviana are similar having bifurcated terminal raphe fissures and more distantly spaced striae, but can be separated based on the position of the terminal raphe fissures, entirely positioned on the valve face in $M$. pimpireviana whereas in $M$. olechiae the terminal fissures continue onto the valve mantle (Zidarova et al. 2016). The bifurcated terminal raphe fissures observed in Muelleria olechiae are also present in for instance $M$. levkoviana VAn de Vijver, Zidarova et Kopalová, M. nogae VAN DE ViJver, Zidarova et Kopalová, M. lototskayae VAN DE VIJVER, M. aequistriata VAN DE ViJVER et SpaUlding, M. kristinae VAN DE VIJVER (VAN DE VIJVER et al. 2010, 2014) but all these taxa either lack the typical more distant striae in the central area (M. nogae, $M$. aequistriata, M. kristinae) and/or present a different valve outline (M. levkoviana: undulated valve margins) or different valve dimensions (M. lototskayae: larger and wider).

Several other Muelleria taxa that are not present in the Antarctic region show some resemblance to the new species. The generitype of Muelleria - Muelleria linearis (MüLLER) FRENGUELLI shares the more distantly spaced radiate striae in the central area and the clearly bifurcated distal raphe endings (SPAULDING et al. 1999). However, the valve outline of Muelleria linearis is always linear to elliptical, whereas smaller valves of Muelleria olechiae are strictly elliptic with only larger valves being linear-lanceolate. Moreover, Muelleria linearis is larger and has only 15 striae in $10 \mu \mathrm{m}$ in the central area.

The Antarctic terrestrial (soil) diatom flora consists mostly of the genera Hantzschia, Humidophila, Luticola and Muelleria. Many species in the Muelleria genus were observed in samples taken from soils, biofilms between stones and rocks often in seepage areas or from coastal areas. Typical examples are $M$. aequistriata, M. australoatlantica, M. kristinae, M. nogae, M. sabbei VAN DE VIJVER et SPAULDING, M. subsabbei, M. rostrata VAN DE VIJVER et SPAULDING and M. tumida (Zidarova 2008; VAN DE ViJVER et al. 2010, 2014). In samples collected from soils on the Ecology Glacier forefield only one other Muelleria taxon (i.e. Muelleria australoatlantica) was regularly observed together with $M$. olechiae (though in a very low abundance). Both species are characterized by similar ecological preferences. The type population of $M$. australoatlantica was described from a rather acid, coastal soil with low organic matter content on Deception Island. It was also found in mosses on King George Island and seepages area on James Ross Island (VAN DE VIJVER et al. 2010). Only in the very species-rich sample EcotC4.2015, characterized by a very low content of organic carbon and a circumneutral $\mathrm{pH}$, more Muelle- ria taxa were observed: $M$. austraoatlanica, M. kristinae, M. pimpireviana, M. rostrata and M. sabbei.

\section{ACKNOWLEDGEMENTS}

The authors wish to thank Prof. dr. M. OLECH (Jagiellonian University, Krakow) for the collection of samples used in this study. Many thanks to MSc. LuKAsz PEszeK (University of Rzeszow, Poland) for his help with scanning electron microscopy. An anonymous reviewer is thanked for the constructive remarks and suggestions that improved this manuscript.

\section{REFERENCES}

BAHLS, L.L. (2014): New diatoms from the American West - a tribute to citizen science. - Proceedings of the Academy of Natural Sciences of Philadelphia 163: 61-84.

Barber, H.G. \& Haworth, E.Y. (1981): A guide to the morphology of the diatom frustule. - 112 pp., Freshwater Biological Association.

KInG, J. C. \& Turner, J. (1997): Antarctic meteorology and climatology. - 409 pp., Cambridge University Press, Cambridge.

Guiry W. in Guiry, M. D. \& Guiry, G. M. (2016): AlgaeBase. World-wide electronic publication, National University of Ireland, Galway. http://www.algaebase.org; searched on 13 October 2016.

Ostrowska, A.; Gawliński, S. \& SzczubiaŁKa, Z. (1991): Metody analizy i oceny właściwości gleb i roślin. Instytut Ochrony Środowiska, Warszawa.

Rakusa-Suszczewski, S. (2002): King George Island - South Shetlnd Islands, Maritime Antarctic. - In: BAYER, L. \& BöLter, M. (eds): Geology of Antarctic Ice-Free Landscapes. Ecological Studies, Vol. - pp. 23-36, SpringerVerlag Berlin Heidelberg.

Round F.E.; Crawford R.M. \& Mann D.G. (1990): The diatoms. Biology \& Morphology of the genera. - 747 pp., Cambridge University Press, Cambridge.

Spaulding, S.A. \& Stoermer, E.F. (1997): Taxonomy and distribution of the genus Muelleria Frenguelli. - Diatom Research 12: 95-115.

Spaulding, S.A.; Kociolek, J.P. \& Wong, D. (1999): A taxonomic and systematic revision of the genus Muelleria (Bacillariophyta). - Phycologia 38: 314-341.

TJuRIN, I. V. (1965): Organičeskoe veščestvo počvy i ego rol' v plodorodii. - Nauka, Moskva.

Van de Vijver, B.; Mataloni, G.; Stanish, L. \& Spaulding S.A. (2010): New and interesting species of the genus Muelleria (Bacillariophyta) from the Antarctic Region and South Africa. - Phycologia 49: 22-41.

Van de Vijver, B.; Zidarova, R. \& Kopalová K. (2014): New species in the genus Muelleria (Bacillariophyta) from the Maritime Antarctic Region. - Fottea 14: 77-90.

ZiDAROVA, R. (2008): Algae from Livingston Island (S Shetland Islands): a check-list. - Phytologia Balcanica 14: 19-35.

Zidarova, R.; Kopalová, K. \& Van de Vijver, B. (2016): Ten new Bacillariophyta species from James Ross Island and the South Shetland Islands (Maritime Antarctic Region). - Phytotaxa 272: 37-62.

(C) Czech Phycological Society (2017)

Received October 25, 2016

Accepted January 31, 2017 